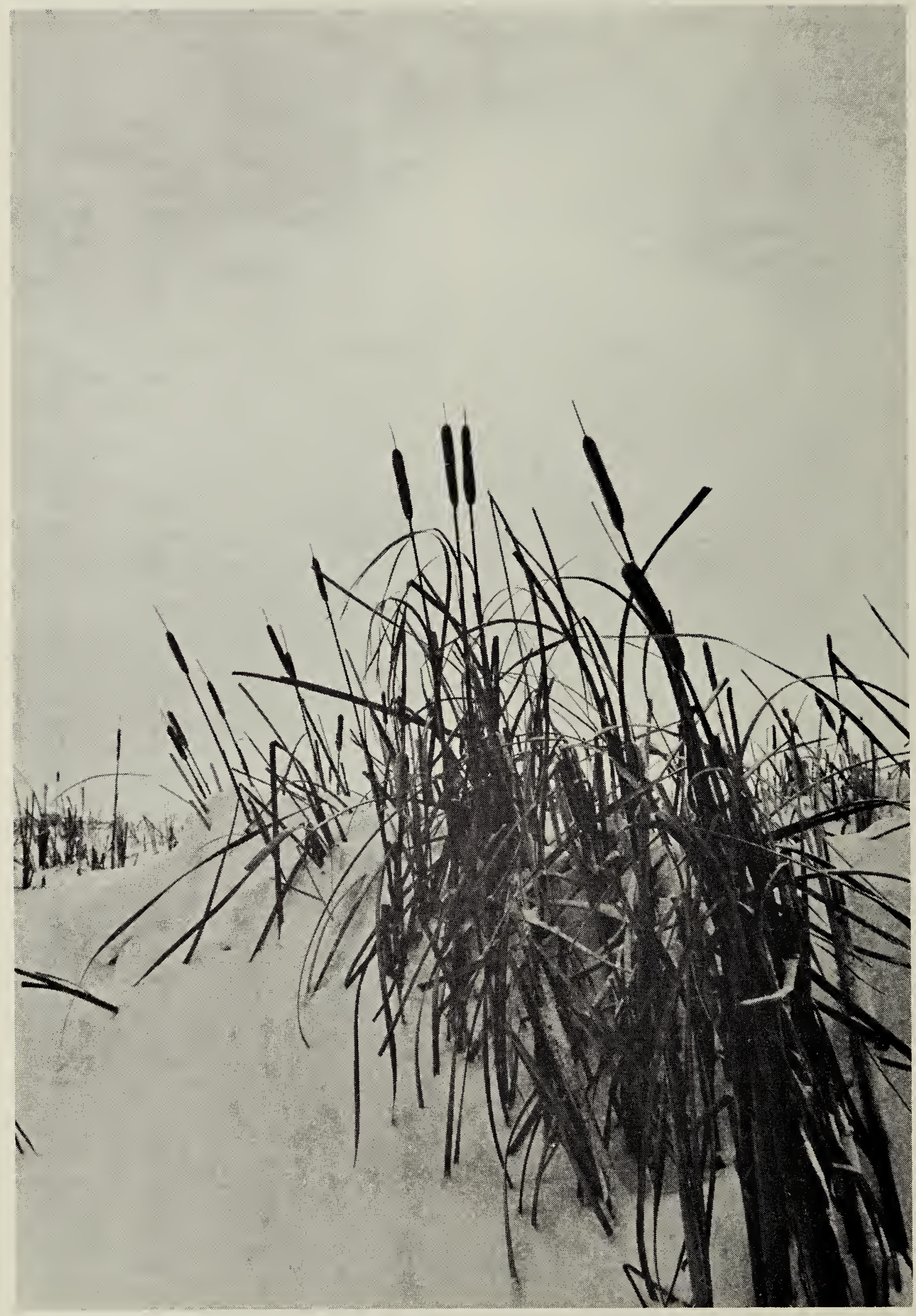

Photo by Robert R. Taylor

Cattails in winter 


\section{A BRIEF NOTE ON BIRDS FEEDING ON THE CAT-TAIL MOTH}

by Robert W. Nero, Regina

When male Red-winged Blackbirds reach their northern breeding grounds in early spring, the marsh is often cold and snowbound and food is noticeably scarce. Consequently, territorial males regularly leave the marsh to search elsewhere for food. Occasionally, however, blackbirds may be seen industriously pecking at the heads of cattail, and this has led some observers to report cattail seeds as a food item for this species. These seeds are minute and it is doubtful that they are eaten at all. Numerous observations (especially in the period from 1948 to 1955 in Wisconsin) have convinced me that blackbirds do, however, prey upon larvae of the Cat-tail Moth (Lymnaecia phragmitella), which regularly overwinter in cattail heads. These small larvae occur in abundance and may be found by carefully breaking open cattail heads. I have found them active in mid-winter, even in Saskatchewan, presumably being kept warm by the insulating effect of the packed cattail down or pappus. They may be found close along the central stalk, where they feed, often two or more occurring in one head. The down is kept from blowing away, once it is released by their feeding activities, by an abundance of silk which the larvae spin, thereby tying the down together (noted by: Comstock, J. H. 1947. An introduction to entomology. Comstock Publ. Co., N.Y. pp. 629-630).

In the process of searching for these concentrated bits of protein blackbirds loosen the down, which then readily blows free, often clinging to their bills and heads. It is the feeding activity of the blackbirds which serves in large measure to bring about the characteristic puffing out of the cattail heads in the spring. On a hot afternoon in July, 1964 at Regina, I was surprised to see dozens of cattail heads literally exploding, a cloud of down bursting forth with each slight gust of wind, in the absence of blackbird activities, and I wondered whether these were infested with maturing larvae. Red-winged Blackbirds, it seems to me, must derive considerable sustenance from this food source, especially in the early spring when insects are otherwise unavailable tc them.

The Yellow-headed Blackbird also is aware of this food source. I noted several males pecking open cattail heads, and evidently feeding on the Cat-tail Moth larvae, early in the morning of May 10, 1958 at Regina. And in October, 1958 I watched a Black-capped Chickadee studiously working on a cattail head, presumably also hunting for this insect, near McLean, some 25 miles east of Regina. Later that year, John E. H. Martin, entomologist with the Canada Department of Agriculture, told me that he had observed a Hairy Woodpecker or a Downy Woodpecker feeding in the winter on cattail heads in eastern Canada.

Observations of birds preying upon the adult Cat-tail Moths, which visit the cattail heads to lay eggs, or which emerge after transforming in the heads or stems, are probably rare. Fortunately, we have the following record made by Frank Brazier (1958. Observations of the birds of Candle Lake. Blue Jay, 16:161) in late June or July, 1958: "Yellowthroats were common near water, one adult male observed carrying food. (This one systematically attacked the cattails, tearing the seed heads apart until a small white moth flew from one which was seized.)" This seems likely to have been a Cat-tail Moth, and the Yellowthroat's behaviour suggests again an awareness of a distinct source of food.

Doubtless others have observed birds feeding or picking at cattail heads. It would be interesting and useful to record such observations and I hope that this brief note will elicit some further comments. 